\title{
Article
}

\section{Differential Expression Profiles of Cell-to-Matrix-Related Molecules in Adrenal Cortical Tumors: Diagnostic and Prognostic Implications}

\author{
Marco Volante ${ }^{1}$, Ida Rapa ${ }^{1}$, Jasna Metovic ${ }^{2}{ }^{\mathbb{D}}$, Francesca Napoli ${ }^{1}$, Cristian Tampieri ${ }^{3}$, Eleonora Duregon ${ }^{1,+}$, \\ Massimo Terzolo ${ }^{4}$ and Mauro Papotti ${ }^{2, *}$
}

1 Department of Oncology, San Luigi Hospital, University of Turin, 10043 Orbassano, Italy; marco.volante@unito.it (M.V.); ida.rapa@unito.it (I.R.); francesca.napoli@unito.it (F.N.); eleonora.duregon@nih.gov (E.D.)

2 Department of Oncology, Città della Salute e della Scienza, University of Turin, 10126 Turin, Italy; jasna.metovic@unito.it

3 Department of Medical Sciences, Città della Salute e della Scienza, University of Turin, 10126 Turin, Italy; cristian.tampieri@unito.it

4 Department of Clinical and Biological Sciences, San Luigi Hospital, University of Turin, 10043 Orbassano, Italy; massimo.terzolo@unito.it

* Correspondence: mauro.papotti@unito.it; Tel.: +39-011-670-5800; Fax: +39-011-633-4623

+ Present address: Translational Gerontology Branch, National Institute on Aging, NIA/NIH, Baltimore, MD 21224, USA.

check for

updates

Citation: Volante, M.; Rapa, I.; Metovic, J.; Napoli, F.; Tampieri, C.; Duregon, E.; Terzolo, M.; Papotti, M. Differential Expression Profiles of Cell-to-Matrix-Related Molecules in Adrenal Cortical Tumors: Diagnostic and Prognostic Implications. J. Pers. Med. 2021, 11, 378. https://doi.org/ $10.3390 /$ jpm11050378

Academic Editor: Cristina L. Ronchi

Received: 26 March 2021

Accepted: 23 April 2021

Published: 6 May 2021

Publisher's Note: MDPI stays neutral with regard to jurisdictional claims in published maps and institutional affiliations.

Copyright: (c) 2021 by the authors. Licensee MDPI, Basel, Switzerland. This article is an open access article distributed under the terms and conditions of the Creative Commons Attribution (CC BY) license (https:/ / creativecommons.org/licenses/by/ $4.0 /)$.

\begin{abstract}
The molecular mechanisms of adrenocortical carcinoma development are incompletely defined. De-regulation of cellular-to-extracellular matrix interactions and angiogenesis appear among mechanisms associated to the malignant phenotype. Our aim was to investigate, employing PCRbased array profiling, 157 molecules involved in cell-to-matrix interactions and angiogenesis in a frozen series of 6 benign and 6 malignant adrenocortical neoplasms, to identify novel pathogenetic markers. In 14 genes, a significant dysregulation was detected in adrenocortical carcinomas as compared to adenomas, most of them being downregulated. Three exceptions-hyaluronan synthase 1 (HAS-1), laminin $\alpha 3$ and osteopontin genes-demonstrated an increased expression in adrenocortical carcinomas of 4.46, 4.23 and 20.32-fold, respectively, and were validated by immunohistochemistry on a series of paraffin-embedded tissues, including 20 adenomas and 73 carcinomas. Osteopontin protein, absent in all adenomas, was expressed in a carcinoma subset $(25 / 73)(p=0.0022)$. Laminin $\alpha 3$ and HAS-1 were mostly expressed in smooth muscle and endothelial cells of the vascular network of both benign and malignant adrenocortical tumors. HAS-1 was also detected in tumor cells, with a more intense pattern in carcinomas. In this group, strong expression was significantly associated with more favorable clinicopathological features. These data demonstrate that cell-to-matrix interactions are specifically altered in adrenocortical carcinoma and identify osteopontin and HAS-1 as novel potential diagnostic and prognostic biomarkers, respectively, in adrenal cortical tumors.
\end{abstract}

Keywords: adrenal cortex; carcinoma; angiogenesis; gene expression; osteopontin; hyaluronan synthase 1

\section{Introduction}

Adrenocortical carcinoma (ACC) is a rare tumor of the adrenal cortex which accounts for no more than $0.2 \%$ of all malignancies. Its differential diagnosis from adrenal cortical adenomas (ACA) has been classically based on several pathological and clinical parameters [1]. None of these is per se indicative of malignancy and is most commonly used in combination in a variety of scoring methods, the Weiss system being the most widely employed. However, such systems are occasionally challenging to apply and/or time consuming despite several implementations introduced in recent years to provide clinically 
relevant information [2-4]. Complementary to histomorphological evaluation, several markers of malignancy have been reported, including p16, p53, topoisomerase II alpha [5-7] and $\mathrm{Ki}-67$. In the latter, cut-off values able to discriminate between benign and malignant lesions were set from $2.5 \%$ to $4 \%$ according to the different authors, whereas in the ACC group, cut-offs ranging from 15 to $20 \%$ have been associated with prognosis [7-12].

Molecular techniques offer the possibility of a distinction between ACA and ACC and, more importantly, an intrinsic profiling of ACC, as consistently different and specific molecular signatures were identified in these tumors, bearing both diagnostic and prognostic implications [13-17]. At the gene expression level, IGF-2 gene up-regulation represents the most specific molecular signature of ACC, a feature related to genetic alterations at the IGF-2 locus reported in a high proportion of hereditary and sporadic ACC [18-20]. IGF-2 immunohistochemical determination has been also proposed as a diagnostic marker of ACC [21]. Among other genes differentially expressed between ACA and ACC, osteopontin and serine threonine kinase 15 were significantly up-regulated (up to 20-fold) in the latter group [17]. In addition, other differential molecular alterations between ACA and ACC were identified within the microRNA or long-non-coding RNA profiles, gene methylation status [22-24] or in the expression levels of single biomarkers, including livin/BIRC7 [25], NOTCH pathway [26] and CYP2W1 [27].

However, a detailed comparative investigation of molecules involved in cell-to-matrix interactions and angiogenesis in ACA and ACC is missing. Individual molecules, only have been investigated in adrenocortical tumors, including vascular endothelial growth factor (VEGF), gelatinases, matrix metalloproteinases and others [28,29]. Serum and tissue VEGF protein levels were found significantly increased in malignant tumors [29-31]. In addition, matrix metalloproteinases and vascular growth factors, aside from being of interest from a pathogenetic and diagnostic point of view, represent promising targets for targeted therapies [32,33].

By means of a selective PCR-based gene array profiling, our study aimed at analyzing the differential expression of genes involved in cell-to-cell and cell-to-matrix interactions, as well as angiogenic processes, in a series of adrenocortical tumors, with the specific purpose of identifying target genes of potential pathogenetic and diagnostic interest in ACC. The decision to investigate such a family of target genes stemmed from a previous publication from our group on the adverse prognostic role of matrix metalloproteinase type 2 (MMP2) expression in ACC [34], as well as from the reported high expression of osteopontin in adrenocortical tumors $[17,35]$.

\section{Materials and Methods}

\subsection{PCR-Based Gene Expression Profile}

Frozen tissues from 12 adrenocortical tumors, including six ACC and six ACA, were analyzed using a PCR-array based method. Total RNA was extracted using QIAzol lysis Reagent (Qiagen, Tokyo, Japan) according to the manufacturer's instructions. Clone DNA was transcribed using $500 \mu \mathrm{g} / \mathrm{mL}$ oligodT (Roche, Mannheim, Germany) and 500M-MLV RT (200 U/ $\mu \mathrm{L})$ (Invitrogen, Carlsbad, CA, USA) according to standard protocols.

Expression profiling was detected in duplicate by two gene Array sets for real-time PCR, which includes SYBR Green-optimized primer sets for 12 housekeeping gene probes and a thoroughly researched panel of 157 relevant genes involved in cell-to-cell and cellto-matrix interactions and angiogenesis (SuperArray Bioscience Corporation, Frederick, MD, USA; codes PAHS-013 and PAHS-024), following the manufacturer's instructions (Supplementary Table S1). PCR reactions were carried out in a fluorescence-based real-time apparatus (ABI PRISM 7900 Sequence Detection System, Taqman; Applied Biosystems, Foster City, CA, USA), and each 96-well plate was analyzed simultaneously under uniform cycling conditions. 


\subsection{Osteopontin, Laminin $\alpha 3$ and HAS-1 Protein Expression in Adrenocortical Tumors: Case Selection and Immunohistochemistry}

Based on the data obtained by gene expression profiling (see below), we aimed at validating the three proteins that resulted in being over expressed in ACC samples. Twenty ACA and 73 ACC tumor tissue samples were analyzed. The former included 42 ACC on tissue micro array (prepared as described elsewhere [36]) and 31 on whole slides. All cases were retrieved from the files at the Pathology Units of AOU San Luigi, Orbassano, and the "Città della Salute e della Scienza", Turin, hospitals. All adrenocortical neoplasms were independently classified by three of us (MV, ED and MP), according to the Weiss system. For the series of 31 ACC cases analyzed on the whole section, clinical information included sex, age, functional status, tumor weight, tumor size, individual Weiss parameters and overall Weiss score, ENSAT stage, type of tumor recurrence (local and or distant metastases), adjuvant mitotane administration and follow up. All cases were surgical specimens of primary tumor resection. Eighteen patients showed disease progression. Among the seventeen cases with available information on the type of progression, 5 had distant metastases, whereas 12 had local (intra-abdominal) dissemination. Adjuvant mitotane was administered in 23 out of 27 patients with this information available. Before starting the analyses, all samples were anonymized by a staff member of the pathology division not involved in the project, and the study was approved by the Institutional Review Board of the San Luigi Hospital (Protocol AMPRECCO, No. 128/2010).

Five micron-thick paraffin sections were collected onto charged slides and processed for osteopontin (polyclonal antibody, diluted 1:650; Sigma Aldrich, Milano, Italy) and Laminin $\alpha 3$ (1:100, rabbit polyclonal antibody, \#PA5-38937, Thermofisher, Waltham, MA, USA) using Ventana BenchMark AutoStainer (Tucson, AZ, USA), whereas hyaluronan synthase 1/HAS-1 (1:250, rabbit polyclonal antibody, \#272680, Abcam, Cambridge, UK) was assessed using the Dako Omnis platform (Agilent Technologies, Santa Clara, CA, USA). Appropriate positive and negative controls were included for each immunohistochemical run. Based on the results obtained, immune reactions were scored as follows: osteopontin was scored as negative or positive in the cytoplasm of tumor cells, laminin $\alpha 3$ was scored in vascular structures, only, into a semiquantitative scale based on density of the vascular network (from 0 to $3+$ ), whereas HAS-1 was both scored in vascular structures (same as above) and in tumor cells based on staining intensity (from 0 to $3+$ ).

\subsection{Statistical Analysis}

All data were analyzed with GraphPad Prism 9.0 (GraphPad Softwares, San Diego, CA, USA). A level of $p<0.05$ was considered statistically significant. Differences in mean gene expression levels between ACC and ACA groups in PCR-array experiments were evaluated by Student's $t$-test. The differential protein expression of immunohistochemical markers in adrenocortical tumors, as well as the correlation between their expression and clinicopathological parameters, were estimated by Chi-square test. Univariate disease free and overall survival analysis of positive and negative tumors for each marker and individual clinical and pathological parameters was based on the Kaplan-Meier product limit estimate of disease free and overall survival distribution. Unadjusted differences between survival curves were tested using the LogRank test. Multivariate Cox regression model was used to assess the association of HAS-1 expression and other clinical and pathological variables with disease free and overall survival by means of the SPSS statistical software version 22 (IBM corporation, Armonk, NY, USA).

\section{Results}

3.1. Gene Expression Profile of Cell-Matrix Interactive and Angiogenic Proteins in Adrenocortical Carcinomas as Compared to Adenomas

A list of all genes that were significantly differentially regulated between adrenocortical carcinoma and adenoma groups is reported in Table 1. For most of the genes analyzed, a general trend (even for those genes with a fold change not reaching the statistical sig- 
nificance) to down-regulation in ACC as compared to ACA was observed. Exceptions were represented by three genes which were significantly up-regulated in the ACC group. Namely, hyaluronan synthase 1 , laminin $\alpha 3$ and osteopontin genes, with a fold change of $4.46,4.23$ and 20.32 times, respectively. Genes just below the statistical significance in their expression fold change between the two groups (with a $p$ value $>0.05$ but $<0.1$, all down regulated) included members of the chemokine family (CXCL-3, -6 and 9 genes), integrin subunits $\alpha 8, \alpha v$ and $\beta 3$, matrix metalloproteinases and related inhibitors (MMP-2, TIMP-1, -2 and 3), epithelial growth factors (TGF $\alpha$ and EREG-epiregulin genes) and the Tie-2/Tek endothelium-specific receptor tyrosine-kinase.

Table 1. Adrenocortical carcinoma versus adenoma significant fold differences in gene expression among 157 molecules investigated.

\begin{tabular}{cccc}
\hline Gene Name & Description & $\begin{array}{c}t \text {-Test } \\
(\boldsymbol{p} \text {-Value })\end{array}$ & Fold Up/Down Regulation \\
\hline BFGF/FGFB & Fibroblast growth factor 2 & 0.0484 & -5.66 \\
\hline DHAND2/Hed & Heart and neural crest derivatives expressed 2 & 0.0234 & -13.61 \\
\hline HAS1 & Hyaluronan synthase 1 & 0.0287 & -9.02 \\
\hline F-TCF/HGFB & Hepatocyte growth factor & 0.0489 & -8.00 \\
\hline IL-1/IL1-BETA & Interleukin 1, $\beta$ & 0.0448 & -16.00 \\
\hline LAMA & Laminin, $\alpha_{2}$ & 0.0391 & 4.23 \\
\hline E170/LAMNA & Laminin, $\alpha_{3}$ & 0.0409 & -3.86 \\
\hline KIAA1907 & Laminin, $\alpha_{5}$ & 0.0280 & -5.20 \\
\hline COX1/COX3 & Prostaglandin-endoperoxide synthase 1 & 0.0442 & 20.32 \\
\hline BNSP/BSPI & (cyclooxygenase) & 0.0450 & -7.45 \\
\hline CLEVER1/FEEL1 & osteopontin, bone sialoprotein I & 0.0215 & -5.53 \\
\hline CED/DPD1 & Stabilin 1 & 0.0365 & -10.82 \\
\hline THBS/TSP & Transforming growth factor, $\beta 1$ & 0.0456 & -11.66 \\
\hline DIF/TNF-alpha & Tumor necrosis factor (TNF superfamily, member 2) & 0.0270 & \\
\hline
\end{tabular}

\subsection{Osteopontin, Laminin $\alpha 3$ and HAS-1 Protein Expression in Adrenocortical Tumors}

By immunohistochemistry, osteopontin was found to be expressed in 25/73 (34\%) ACC samples, whereas it was absent in all 20 ACA tested $(p=0.0022)$ (Table 2$)$. The pattern of staining in ACC tumor cells was cytoplasmic, either diffuse or with a peculiar dot-like paranuclear appearance, or a combination of the two (Figure 1) at comparable frequencies. No specific correlation was observed between the presence or absence of staining nor the two staining patterns or the intensity of staining with morphological or clinical features in the 31 ACC patients with clinical information available. 
Table 2. Immunoexpression of Laminin $\alpha 3$, HAS-1 and osteopontin in a series of 73 adrenocortical carcinomas and 20 adrenocortical adenomas.

\begin{tabular}{|c|c|c|c|c|}
\hline & IHC Semiquantitative Score & * ACC (\#73) & $\S$ ACA (\#20) & $p$ Value \\
\hline \multirow{4}{*}{ Laminin $\alpha 3$ (vascular network) } & 0 & $13(17.8 \%)$ & $3(15 \%)$ & \multirow[t]{4}{*}{0.04} \\
\hline & $1+$ & $20(27.4 \%)$ & $11(55 \%)$ & \\
\hline & $2+$ & $23(31.5 \%)$ & $6(30 \%)$ & \\
\hline & $3+$ & $17(23.3 \%)$ & 0 & \\
\hline \multirow{4}{*}{ HAS-1 (tumor cells) } & 0 & $42(57.5 \%)$ & $13(65 \%)$ & \multirow{4}{*}{0.55} \\
\hline & $1+$ & $17(23.3 \%)$ & $5(25 \%)$ & \\
\hline & $2+$ & $7(9.6 \%)$ & $2(10 \%)$ & \\
\hline & $3+$ & $7(9.6 \%)$ & 0 & \\
\hline \multirow{4}{*}{ HAS-1 (vascular network) } & 0 & $12(16.4 \%)$ & $2(10 \%)$ & \multirow{4}{*}{0.51} \\
\hline & $1+$ & $21(28.8 \%)$ & $9(45 \%)$ & \\
\hline & $2+$ & $18(24.7 \%)$ & $5(25 \%)$ & \\
\hline & $3+$ & $22(30.1 \%)$ & $4(20 \%)$ & \\
\hline \multirow{2}{*}{ Osteopontin (tumor cells) } & negative & $48(65.8 \%)$ & $20(100 \%)$ & \multirow{2}{*}{0.0022} \\
\hline & positive & $25(34.2 \%)$ & 0 & \\
\hline
\end{tabular}

Abbreviations: IHC: immunohistochemistry; * ACC: adrenocortical carcinoma, 31 cases on whole section and 42 on TMA; $\$$ ACA: adrenocortical adenoma (all on whole section).

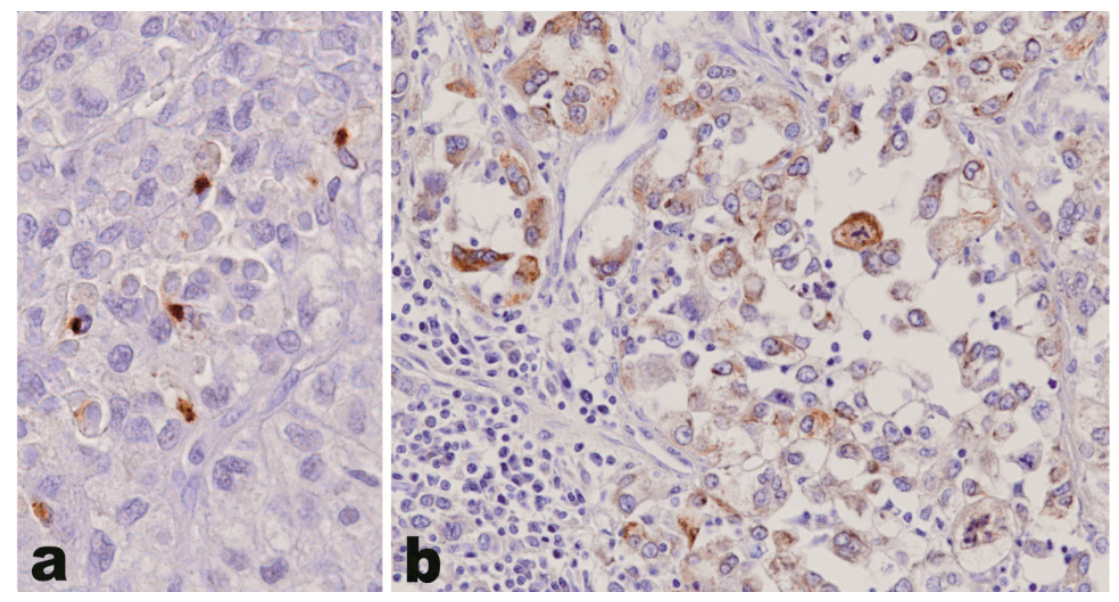

Figure 1. Osteopontin expression in adrenocortical carcinoma. The pattern of staining in adrenocortical carcinoma tumor cells is cytoplasmic, either with a peculiar dot-like paranuclear appearance (a) or diffuse within the cytoplasm (b). The intratumoral lymphocytes (b, bottom left) are un-reactive (original magnification $400 \times$ ).

Laminin $\alpha 3$ was expressed both in ACA and ACC, but with a statistically significant increase of density of staining in ACC. The positive staining was observed in both ACA and ACC exclusively in vascular structures, whereas tumor cells were consistently negative in both tumor types (Figure 2a,b). As for osteopontin, no correlation between laminin $\alpha 3$ and clinical or pathological parameters in the series of ACC was observed. HAS-1 did not show a statistically different prevalence of staining in ACA and ACC and was expressed both in vascular structures and in tumor cells, in this latter case with a diffuse cytoplasmic pattern with occasional membrane reinforcement (Figure 2c,d). 


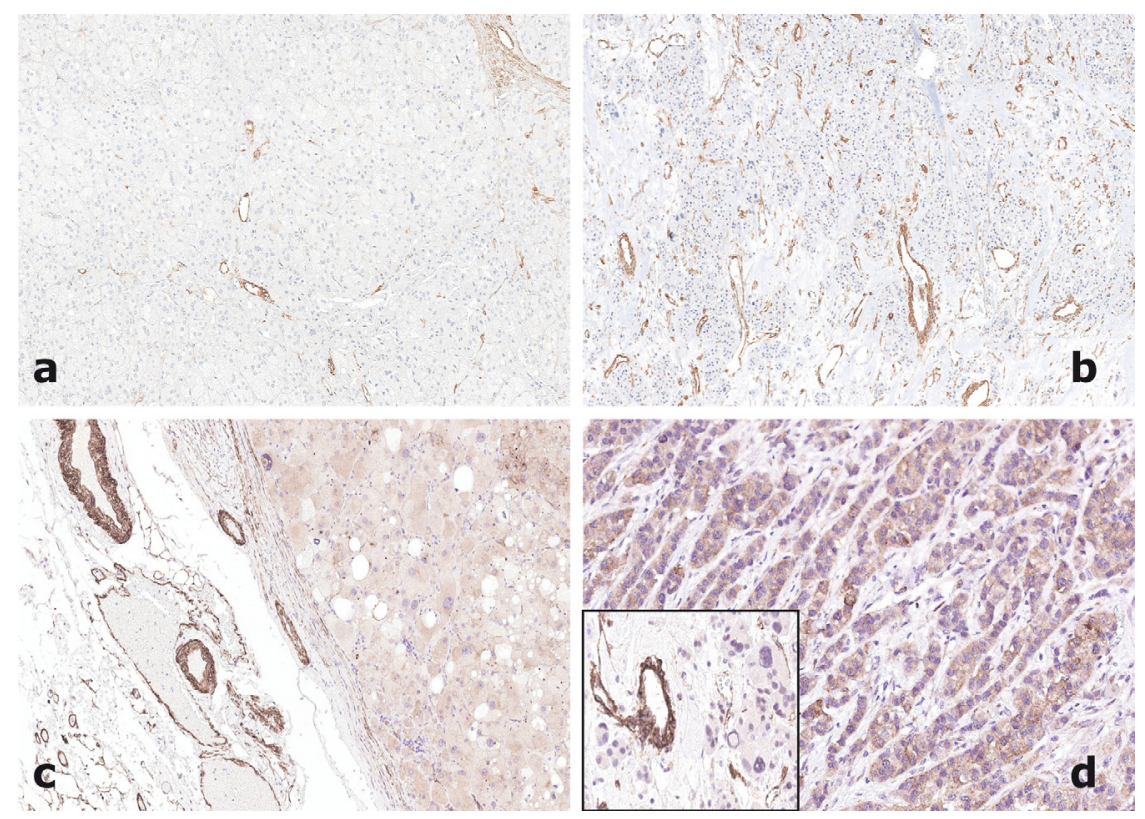

Figure 2. Laminin $\alpha 3$ immunoexpression is restricted to the vascular network of both an adrenocortical adenoma with rare and thin vessels $(\mathbf{a}, 100 \times)$ and an adrenocortical carcinoma containing numerous small and medium size vessels $(\mathbf{b}, 100 \times)$. Hyaluronan synthase- 1 is also strongly expressed by smooth muscle cells of vessel walls in both adrenocortical adenoma (c, 100×) and carcinoma (d inset, 200×). In addition, tumor cells of adenomas present more frequently a negative or weakly positive pattern of staining $(\mathbf{c}, 100 \times)$, while carcinoma cells may show a strong cytoplasmic reactivity $(\mathbf{d}, 100 \times)$.

HAS-1 was also detectable in the cytoplasm of peritumoral normal adrenal cells, with a more intense staining in cells of the fasciculata zone. HAS-1 positivity in vascular structures was not associated with any of the clinical or pathological variables in the series of 31 ACCs with clinical and pathological annotates.

By contrast, HAS-1 negative expression in tumor cells was significantly associated with features of aggressiveness, such as higher mitotic index, presence of atypical mitoses, and poor disease outcome (Table 3). Negative HAS-1 staining in tumor cells was also more frequently observed in female patients and at lower age of onset.

Table 3. Major clinico-pathological features according to HAS-1 positivity in tumor cells (\#31 cases on whole section).

\begin{tabular}{|c|c|c|c|c|}
\hline Parameter & & HAS-1 Positive & HAS-1 Negative & $p$ Value \\
\hline \multirow{2}{*}{ Sex } & $\mathrm{M}$ & 8 & 6 & \multirow{2}{*}{0.02} \\
\hline & $\mathrm{F}$ & 7 & 10 & \\
\hline \multirow{2}{*}{ Age } & $<46^{*}$ & 3 & 10 & \multirow{2}{*}{0.02} \\
\hline & $\geq 46$ & 12 & 6 & \\
\hline \multirow{2}{*}{ Functional status } & Nonfunctioning & 8 & 10 & \multirow{2}{*}{0.62} \\
\hline & Functioning $^{+}$ & 7 & 6 & \\
\hline \multirow{2}{*}{ Tumor weight (g) } & $<275^{*}$ & 10 & 9 & \multirow{2}{*}{0.55} \\
\hline & $\geq 275$ & 5 & 7 & \\
\hline \multirow{2}{*}{ Tumor size $(\mathrm{cm})$} & $<11^{*}$ & 10 & 6 & \multirow{2}{*}{0.10} \\
\hline & $\geq 11$ & 5 & 10 & \\
\hline
\end{tabular}


Table 3. Cont.

\begin{tabular}{|c|c|c|c|c|}
\hline Parameter & & HAS-1 Positive & HAS-1 Negative & $p$ Value \\
\hline \multirow{2}{*}{ Mitoses } & $<8^{*}$ & 10 & 4 & \multirow{2}{*}{0.02} \\
\hline & $\geq 8$ & 5 & 12 & \\
\hline \multirow{2}{*}{ Atypical mitoses } & absent & 11 & 6 & \multirow{2}{*}{0.045} \\
\hline & present & 4 & 10 & \\
\hline \multirow{2}{*}{ Necrosis } & absent & 4 & 1 & \multirow{2}{*}{0.12} \\
\hline & present & 11 & 15 & \\
\hline \multirow{2}{*}{ Venous invasion } & absent & 2 & 6 & \multirow{2}{*}{0.12} \\
\hline & present & 13 & 10 & \\
\hline \multirow{2}{*}{ Sinusoid invasion } & absent & 8 & 9 & \multirow{2}{*}{0.87} \\
\hline & present & 7 & 7 & \\
\hline \multirow{2}{*}{ Capsular invasion } & absent & 8 & 8 & \multirow{2}{*}{0.85} \\
\hline & present & 7 & 8 & \\
\hline \multirow{2}{*}{ Nuclear atypia } & absent & 3 & 4 & \multirow{2}{*}{0.74} \\
\hline & present & 12 & 12 & \\
\hline \multirow{2}{*}{ Weiss score } & $3-6$ & 8 & 7 & \multirow{2}{*}{0.59} \\
\hline & $7-9$ & 7 & 9 & \\
\hline \multirow{3}{*}{ ENSAT stage } & I & 4 & 0 & \multirow{3}{*}{0.068} \\
\hline & II & 10 & 13 & \\
\hline & III & 1 & 3 & \\
\hline \multirow{2}{*}{$\begin{array}{l}\text { Mitotane treatment } \\
\text { (4 cases missing) }\end{array}$} & no & 3 & 1 & \multirow{2}{*}{0.60} \\
\hline & yes & 12 & 11 & \\
\hline \multirow{2}{*}{ Status } & NED & 10 & 3 & \multirow{2}{*}{0.0069} \\
\hline & AWD/DOD & 5 & 13 & \\
\hline Median DFS & months & not reached & 49 & 0.040 \\
\hline Median OS & months & not reached & 17 & 0.197 \\
\hline
\end{tabular}

Legend. DFS: disease free survival; OS: overall survival; ${ }^{*}$ : median value; ${ }^{+}$: functioning tumors were defined according to the presence of an evident clinical syndrome and included among the hormones produced cortisol, aldosterone, and androgens; NED: no evidence of disease; AWD: alive with disease; DOD: dead of disease.

Disease free (DFS) and overall (OS) survival analyses did not show any significant difference in whether patients were positive or negative for osteopontin or laminin $\alpha 3$. Laminin $\alpha 3$ scores $0-1$ had a median DFS and OS of 62 months and "undefined", respectively, as compared to median DFS and OS of 30 and 61 months, respectively, in cases with 2-3 scores (all $p$ values not significant). Osteopontin expression was also not associated with survival, with median DFS of 37 and 22 months and median OS "undefined" and of 61 months, in negative and positive cases, respectively (all $p$ values not significant). HAS-1 density of expression in the vascular network was not associated to a specific survival, with median DFS of 22 and 49 months and median OS both "undefined", in cases with score $0-2$ and with score 3 , respectively (all $p$ values not significant). Interestingly, negative HAS-1 expression was associated with shorter survival (Figure 3). In fact, a trend towards significance was observed for OS, with a 49-month median survival in negative cases as compared to "undefined" in positive cases (Log rank test $p$ value 0.197, HR 2.15). Moreover, DFS was significantly different in HAS-1 negative and positive cases, with a median survival of 17 and "undefined", respectively (Log rank test $p$ value 0.040, HR 2.77). 

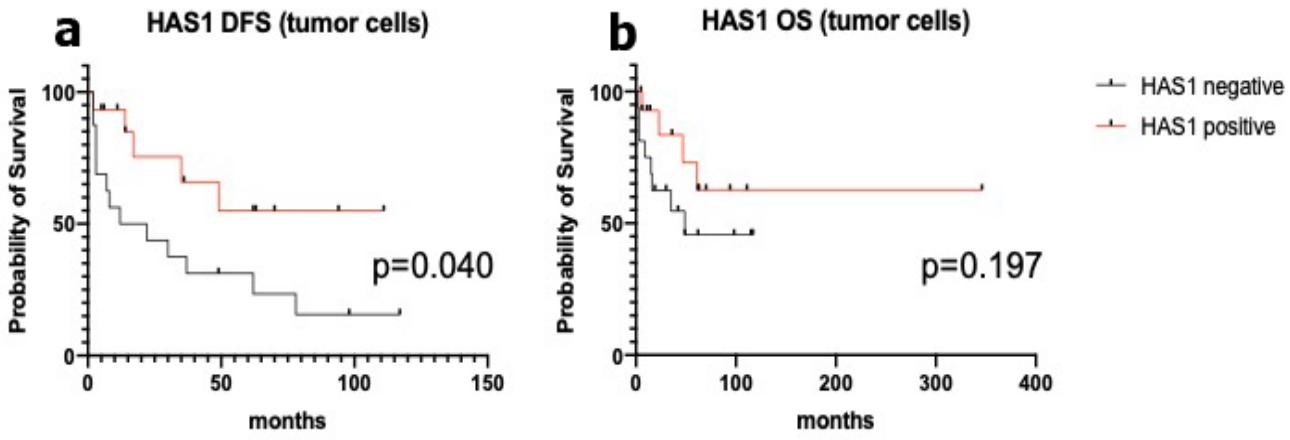

Figure 3. Univariate disease free (a) and overall (b) survival analysis in HAS-1 tumor cell positive and negative adrenocortical carcinomas.

To test the interference of other clinical and pathological factors with HAS-1 in univariate survival analyses, all variables statistically associated with HAS-1 tumor cell positive expression having a $p$-value of $<0.2$ (see Table 3) were tested in univariate disease free and overall survival analyses. Among those, age, ENSAT stage presence of necrosis and presence of vascular invasion failed to show statistical significance in both disease free and overall survival analyses. By contrast, male sex, size above median $(11 \mathrm{~cm})$, mitotic index above median (11 mitotic figures in 50 high power fields) and presence of atypical mitoses were all associated with shorter survival with a $p$-value $<0.2$ ( $p$ values of 0.085 , $0.011,0.088$ and 0.078 , respectively) and were included in multivariable cox regression analysis together with HAS-1. Independent adverse prognostic impact in terms of disease free survival was retained for male sex and large size (0.036 and 0.028 , respectively) only. At overall survival analysis, size above median and mitotic index above median were associated with a $p$-value $<0.2$ ( $p$-values of 0.082 and 0.084 , respectively) and were included in multivariable cox regression analysis together with HAS-1. None of the parameters reached statistical significance, tumor size showing the most significant $p$-value $(0.065)$.

\section{Discussion}

By means of a selective PCR-based gene array approach, we here demonstrated a differential expression of several genes involved in angiogenesis and cell-to-matrix interactions in ACC as compared to ACA. Previous molecular studies in adrenocortical tumors showed peculiar gene expression profiles in ACC as compared to ACA, up-regulation of IGF-2 gene and down-regulation of genes involved in steroidogenesis being the most specific molecular signatures of ACC $[17,19,20]$. The major advantage of wide gene expression profiling is to generate a large amount of information, thus providing a molecular classification of tumors. On the other hand, data from different studies are not easily comparable and it is sometimes difficult to transpose such complexity of information onto a diagnostic ground. Our approach was to screen a limited number of genes involved in cellto-matrix interactions and angiogenesis that the previous literature supported to be altered in adrenal cancer [28-31,34,35], to search for potential pathogenetic or clinically relevant biomarkers. In general, most of the genes that showed a differential expression in ACC as compared to ACA are active regulators of angiogenesis (such as Fibroblast growth factor 2, Hepatocyte growth factor, Prostaglandin-endoperoxide synthase 1, Transforming growth factor, $\beta 1$ and Thrombospondin 1). Moreover, several other angiogenesis-regulating genes showed an altered regulation in ACC as compared to ACA, while not reaching statistical significance. Notably, the vast majority of these genes showed a peculiar down regulation. This finding is partially surprising, but it might fit with the consistent down-regulation of several growth factor receptors described by Giordano and co-workers in ACC [17] and it might represent either the consequence of the different vascular network in ACA vs. ACC or the consequence of decreased tissue expression. Due to the heterogeneous biological functions of these molecules, it is difficult, however, to hypothesize the biological meaning of our findings, in the lack of functional experiments that represents a major limitation 
of our study. Moreover, among the genes that showed no differential or slightly lower expression in ACC, the various matrix metalloproteinases, their specific inhibitors, and VEGF isoforms should be mentioned since their related proteins have been found to be over-expressed in ACC tumor cells [29-31]. In this respect, the absence of a differential expression of the corresponding genes between ACA and ACC in our series may more probably reflect a balance between the integrity of the vascular network and neo-angiogenic capabilities in the two tumor types, the equilibrium being more shifted to the former in ACA and to the latter in ACC [31].

An altered expression of laminin isoforms was observed in the current series of ACC, with a higher expression of the $\alpha 3$ and lower expression of $\alpha 2$ and $\alpha 5$ laminin isoforms, as opposed to ACA. This observation is interesting since $\alpha 2$ and $\alpha 5$ laminin isoforms are consistently expressed in the basal membrane of the normal adult adrenal cortex, whereas $\alpha 3$ isoform is virtually absent [37], and might be related to structural alterations of the basal membrane in ACC tissue [38]. In fact, the reduced expression of $\alpha 2$ and $\alpha 5$ laminin isoforms may be correlated with the morphological finding of reticulin framework disruption in carcinomas [38], while overexpression of laminin $\alpha 3$ might be related to the higher expression levels of this isoform observed in the dense intratumoral vascular network of ACC.

With regard to other molecules than laminin $\alpha 3$ having an increased expression in ACC, osteopontin had the highest fold difference, a finding in agreement with previous gene array data [17] and with the report of Weisman and co-workers [35]. It was therefore further analyzed in a large series of adrenocortical tumors by means of immunohistochemistry to test its tissue localization pattern. Osteopontin expression was restricted to a fraction of malignant cases, being absent in all ACAs, at variance with the findings of Weismann and co-workers who observed a heterogeneous expression of OPN in both ACA and ACC, with a staining often restricted to single cells or small clusters. In our series, however, osteopontin provided a specificity of $100 \%$ but a sensitivity of $34 \%$ only, thus limiting its value as a diagnostic tool in the differential diagnosis between benign and malignant adrenocortical tumors.

Osteopontin is a secreted phosphoprotein that binds multiple integrins including $\alpha v \beta 1, \alpha v \beta 3$, and $\alpha v \beta 5$ [35] and is involved in several cellular processes, such as cell attachment, spreading and migration, homing of lymphocytes and other hematopoietic cells and vascular remodeling $[39,40]$.

Moreover, osteopontin has been demonstrated to be over-expressed in many human tumors, including carcinomas of the breast [41], lung [42], ovary [43], stomach [44], liver [45], and prostate [46] as well as mesothelioma [47], and it was proposed as a potential prognostic marker in many of these neoplasms. In particular, osteopontin expression is induced by hypoxia and its prognostic role in solid tumors is partially explained by its interplay with other hypoxia-related molecules and angiogenic factors, at least in head and neck and prostate cancer $[48,49]$.

Interestingly, in different cellular models osteopontin up-regulates the expression of hyaluronan synthases. In breast cancer cells, osteopontin has been shown to upregulate HAS-2, another enzyme involved in the synthesis of hyaluronan, a major component of the extracellular matrix, with a role in several cellular functions, including cell proliferation and migration [50]. Moreover, in osteoarthritic-derived chondrocytes, osteopontin has been shown to promote the expression of the HAS-1 gene [51]. In the present series, HAS-1 was identified by immunohistochemistry in the smooth muscle and endothelial cells of blood vessels of both benign and malignant adrenocortical tumors, with no differences except for the denser vascular network in ACC. In addition, HAS-1 was also detected in the tumor cells of a fraction of ACC $(42 \%)$, but only occasionally and weakly in adenoma tumor cells (although this difference was not statistically significant). This finding is not in agreement with gene expression data on the frozen series and claims that HAS-1 has no role as a diagnostic marker in the differential diagnosis between ACA and ACC. However, the lack of a direct correlation between HAS-1 gene and protein data in ACC vs. ACA might be 
explained by the wide heterogeneity of protein distribution and intensity in blood vessels, as well as in tumor cells. In fact, although with no statistical significance comparing the different subgroups, both in tissue blood vessels and in tumor cells, ACC showed a higher rate of HAS-1 intense (3+ score) staining, which might explain the overexpression observed at the gene level. More intriguingly, HAS-1 expression in ACC tumor cells was associated with a lower mitotic rate, a lower prevalence of atypical mitotic figures and a better outcome. The prognostic significance of HAS- 1 in cancers is equivocal and has been studied either in cancer cells or in cancer stroma, including cancer-associated fibroblasts [52-54]. However, in agreement with our findings, a negative prognostic role of HAS-1 downregulation in cancer cells has been described in lung cancer [55] and melanoma [56]. Survival analysis in our study has several limitations, including the small sample size and incomplete data on progression that could not allow a disease-specific survival, but overall survival only. The association of negative HAS- 1 tumor cell expression with shorter disease free survival, that showed statistical significance in univariate analysis, could not be validated as an independent factor in multivariate analysis due to the possible interference with other significant negative prognostic factors such as tumor size. Nevertheless, even though our data need to be confirmed in a larger series, the prognostic impact of HAS-1 expression claim a role for the interplay between cancer cells and the stromal environment as a relevant field of investigation in ACC, which is at variance with several other cancer models, has not yet been explored in detail.

\section{Conclusions}

In conclusion, the present paper showed that ACC is associated to an altered expression of several genes involved in angiogenesis and cell-to-cell/cell-to-matrix interactions, possibly as the result of unbalanced vasculature and neo-angiogenic properties. Among these, osteopontin is selectively expressed in ACC tumor cells and represents a potential diagnostic marker, although with a remarkably low sensitivity, whereas negative HAS-1 expression in tumor cells characterizes a subset of ACC with a more aggressive clinical outcome.

Supplementary Materials: The following are available online at https:/ /www.mdpi.com/article/ 10.3390/jpm11050378/s1, Table S1: Panel of 157 genes involved in cell-to-cell and cell-to-matrix interactions and angiogenesis tested in the present study.

Author Contributions: Conceptualization, M.P., M.V.; methodology, M.V.; formal analysis, M.P., M.V., I.R., E.D., F.N., J.M., C.T.; investigation, I.R., M.V., J.M., F.N., C.T.; data curation, M.V., M.P., J.M.; writing—original draft preparation, M.V., M.P.; writing—review and editing, M.V., M.P., J.M., E.D., I.R., M.T.; visualization, M.V.; supervision, M.P.; project administration, M.V.; funding acquisition, M.V., M.P. All authors have read and agreed to the published version of the manuscript.

Funding: Work partially supported by grants from Regione Piemonte (Progetto Ricerca Sanitaria Finalizzata 2007, D.G.R. n. 35-4231, 06.11.2006 to MV) and from the Associazione Italiana per la Ricerca sul Cancro, AIRC Milan (IG10795 to MP).

Institutional Review Board Statement: This study was conducted in accordance with the ethical standards of Declaration of Helsinki. This study was approved by the Institutional Review Board of the San Luigi Hospital (Protocol AMPRECCO, No. 128/2010).

Informed Consent Statement: Considering the retrospective nature of this research protocol with no impact on patients' treatment and the use of anonymized data only, written consent was not required. Before the study started, all cases were de-identified and coded by a pathology staff member not involved in the study, and all data were accessed anonymously.

Data Availability Statement: Not applicable.

Acknowledgments: E.D. and J.M. participated in the PhD program of the University of Torino. E.D. is currently supported by the Intramural Research Program of the National Institute on Aging, National Institutes of Health. Graphical abstract was created with BioRender.com (accessed on 27 April 2021). 
Conflicts of Interest: The authors declare no conflict of interest.

\section{References}

1. WHO Classification of Tumours of Endocrine Organs; Lloyd, R.V., Osamura, R.Y., Klöppel, G., Rosai, J., Eds.; IARC (International Agency for Research on Cancer), Scientific Publications: Lyon, France, 2017; Volume 10, pp. 163-173.

2. Giordano, T.J.; Berney, D.; de Krijger, R.R.; Erickson, L.; Fassnacht, M.; Mete, O.; Papathomas, T.; Papotti, M.; Sasano, H.; Thompson, L.D.R.; et al. Data set for reporting of carcinoma of the adrenal cortex: Explanations and recommendations of the guidelines from the International Collaboration on Cancer Reporting. Hum. Pathol. 2020. [CrossRef]

3. Duregon, E.; Fassina, A.; Volante, M.; Nesi, G.; Santi, R.; Gatti, G.; Cappellesso, R.; Dalino Ciaramella, P.; Ventura, L.; Gambacorta, M.; et al. The reticulin algorithm for adrenocortical tumor diagnosis: A multicentric validation study on 245 unpublished cases. Am. J. Surg. Pathol. 2013, 37, 1433-1440. [CrossRef] [PubMed]

4. Duregon, E.; Cappellesso, R.; Maffeis, V.; Zaggia, B.; Ventura, L.; Berruti, A.; Terzolo, M.; Fassina, A.; Volante, M.; Papotti, M. Validation of the prognostic role of the "Helsinki Score" in 225 cases of adrenocortical carcinoma. Hum. Pathol. 2017, 62, 1-7. [CrossRef] [PubMed]

5. Pilon, C.; Pistorello, M.; Moscon, A.; Altavilla, G.; Pagotto, U.; Boscaro, M.; Fallo, F. Inactivation of the p16 tumor suppressor gene in adrenocortical tumors. J. Clin. Endocrinol. Metab. 1999, 84, 2776-2779. [CrossRef] [PubMed]

6. Pinto, E.M.; Billerbeck, A.E.C.; Fragoso, M.C.B.V.; Mendonca, B.B.; Latronico, A.C. Deletion mapping of chromosome 17 in benign and malignant adrenocortical tumors associated with the Arg337His mutation of the p53 tumor suppressor protein. J. Clin. Endocrinol. Metab. 2005, 90, 2976-2981. [CrossRef] [PubMed]

7. Stojadinovic, A.; Ghossein, R.A.; Hoos, A.; Nissan, A.; Marshall, D.; Dudas, M.; Cordon-Cardo, C.; Jaques, D.P.; Brennan, M.F. Adrenocortical carcinoma: Clinical, morphologic, and molecular characterization. J. Clin. Oncol. Off. J. Am. Soc. Clin. Oncol. 2002, 20, 941-950. [CrossRef] [PubMed]

8. Aubert, S.; Wacrenier, A.; Leroy, X.; Devos, P.; Carnaille, B.; Proye, C.; Wemeau, J.L.; Lecomte-Houcke, M.; Leteurtre, E. Weiss system revisited. Am. J. Surg. Pathol. 2002, 26, 1612-1619. [CrossRef] [PubMed]

9. Terzolo, M.; Boccuzzi, A.; Bovio, S.; Cappia, S.; De Giuli, P.; Alì, A.; Paccotti, P.; Porpiglia, F.; Fontana, D.; Angeli, A. Immunohistochemical assessment of Ki-67 in the differential diagnosis of adrenocortical tumors. Urology 2001, 57, 176-182. [CrossRef]

10. Papathomas, T.G.; Pucci, E.; Giordano, T.J.; Lu, H.; Duregon, E.; Volante, M.; Papotti, M.; Lloyd, R.V.; Tischler, A.S.; van Nederveen, F.H.; et al. An International Ki67 reproducibility study in adrenal cortical carcinoma. Am. J. Surg. Pathol. 2016, 40, 569-576. [CrossRef]

11. Duregon, E.; Molinaro, L.; Volante, M.; Ventura, L.; Righi, L.; Bolla, S.; Terzolo, M.; Sapino, A.; Papotti, M.G. Comparative diagnostic and prognostic performances of the hematoxylin-eosin and phospho-histone $\mathrm{H} 3$ mitotic count and Ki-67 index in adrenocortical carcinoma. Mod. Pathol. 2014, 27, 1246-1254. [CrossRef]

12. Beuschlein, F.; Weigel, J.; Saeger, W.; Kroiss, M.; Wild, V.; Daffara, F.; Libé, R.; Ardito, A.; Al Ghuzlan, A.; Quinkler, M.; et al. Major prognostic role of Ki67 in localized adrenocortical carcinoma after complete resection. J. Clin. Endocrinol. Metab. 2015, 100, 841-849. [CrossRef]

13. Assié, G.; Jouinot, A.; Fassnacht, M.; Libé, R.; Garinet, S.; Jacob, L.; Hamzaoui, N.; Neou, M.; Sakat, J.; de La Villéon, B.; et al. Value of molecular classification for prognostic assessment of adrenocortical carcinoma. JAMA Oncol. 2019, 5. [CrossRef]

14. Assié, G.; Letouzé, E.; Fassnacht, M.; Jouinot, A.; Luscap, W.; Barreau, O.; Omeiri, H.; Rodriguez, S.; Perlemoine, K.; René-Corail, F.; et al. Integrated genomic characterization of adrenocortical carcinoma. Nat. Genet. 2014, 46, 607-612. [CrossRef]

15. Guo, J.; Gu, Y.; Ma, X.; Zhang, L.; Li, H.; Yan, Z.; Han, Y.; Xie, L.; Guo, X. Identification of hub genes and pathways in adrenocortical carcinoma by integrated bioinformatic analysis. J. Cell. Mol. Med. 2020, 24, 4428-4438. [CrossRef] [PubMed]

16. Zheng, S.; Cherniack, A.D.; Dewal, N.; Moffitt, R.A.; Danilova, L.; Murray, B.A.; Lerario, A.M.; Else, T.; Knijnenburg, T.A.; Ciriello, G.; et al. Comprehensive pan-genomic characterization of adrenocortical carcinoma. Cancer Cell 2016, 29, 723-736. [CrossRef] [PubMed]

17. Giordano, T.J.; Thomas, D.G.; Kuick, R.; Lizyness, M.; Misek, D.E.; Smith, A.L.; Sanders, D.; Aljundi, R.T.; Gauger, P.G.; Thompson, N.W.; et al. Distinct transcriptional profiles of adrenocortical tumors uncovered by DNA microarray analysis. Am. J. Pathol. 2003, 162, 521-531. [CrossRef]

18. Gicquel, C.; Raffin-Sanson, M.L.; Gaston, V.; Bertagna, X.; Plouin, P.F.; Schlumberger, M.; Louvel, A.; Luton, J.P.; Le Bouc, Y. Structural and functional abnormalities at $11 \mathrm{p} 15$ are associated with the malignant phenotype in sporadic adrenocortical tumors: Study on a series of 82 tumors. J. Clin. Endocrinol. Metab. 1997, 82, 2559-2565. [CrossRef] [PubMed]

19. De Fraipont, F.; El Atifi, M.; Cherradi, N.; Le Moigne, G.; Defaye, G.; Houlgatte, R.; Bertherat, J.; Bertagna, X.; Plouin, P.F.; Baudin, E.; et al. Gene expression profiling of human adrenocortical tumors using complementary deoxyribonucleic acid microarrays identifies several candidate genes as markers of malignancy. J. Clin. Endocrinol. Metab. 2005, 90, 1819-1829. [CrossRef] [PubMed]

20. Velázquez-Fernández, D.; Laurell, C.; Geli, J.; Höög, A.; Odeberg, J.; Kjellman, M.; Lundeberg, J.; Hamberger, B.; Nilsson, P.; Bäckdahl, M. Expression profiling of adrenocortical neoplasms suggests a molecular signature of malignancy. Surgery 2005, 138, 1087-1094. [CrossRef]

21. Schmitt, A.; Saremaslani, P.; Schmid, S.; Rousson, V.; Montani, M.; Schmid, D.M.; Heitz, P.U.; Komminoth, P.; Perren, A. IGFII and MIB1 immunohistochemistry is helpful for the differentiation of benign from malignant adrenocortical tumours. Histopathology 2006, 49, 298-307. [CrossRef] [PubMed] 
22. Agosta, C.; Laugier, J.; Guyon, L.; Denis, J.; Bertherat, J.; Libé, R.; Boisson, B.; Sturm, N.; Feige, J.J.; Chabre, O.; et al. MiR-483-5p and miR-139-5p promote aggressiveness by targeting $\mathrm{N}$-myc downstream-regulated gene family members in adrenocortical cancer. Int. J. Cancer 2018, 143, 944-957. [CrossRef]

23. Xiao, H.; He, W.; Chen, P.; Xu, D.; Zeng, G.; Li, Z.; Huang, M.; Wang, X.; DiSanto, M.E.; Zhang, X. Identification of seven aberrantly methylated and expressed genes in adrenocortical carcinoma. Front. Endocrinol. 2019, 10, 472. [CrossRef] [PubMed]

24. Buishand, F.O.; Liu-Chittenden, Y.; Fan, Y.; Tirosh, A.; Gara, S.K.; Patel, D.; Meerzaman, D.; Kebebew, E. Adrenocortical tumors have a distinct, long, non-coding RNA expression profile and LINC00271 is downregulated in malignancy. Surgery 2020, 167, 224-232. [CrossRef] [PubMed]

25. Altieri, B.; Sbiera, S.; Della Casa, S.; Weigand, I.; Wild, V.; Steinhauer, S.; Fadda, G.; Kocot, A.; Bekteshi, M.; Mambretti, E.M.; et al. Livin/BIRC7 expression as malignancy marker in adrenocortical tumors. Oncotarget 2017, 8, 9323-9338. [CrossRef]

26. Ronchi, C.L.; Sbiera, S.; Altieri, B.; Steinhauer, S.; Wild, V.; Bekteshi, M.; Kroiss, M.; Fassnacht, M.; Allolio, B. Notch1 pathway in adrenocortical carcinomas: Correlations with clinical outcome. Endocr. Relat. Cancer 2015, 22, 531-543. [CrossRef] [PubMed]

27. Ronchi, C.L.; Sbiera, S.; Volante, M.; Steinhauer, S.; Scott-Wild, V.; Altieri, B.; Kroiss, M.; Bala, M.; Papotti, M.; Deutschbein, T.; et al. CYP2W1 is highly expressed in adrenal glands and is positively associated with the response to mitotane in adrenocortical carcinoma. PLoS ONE 2014, 9, e105855. [CrossRef] [PubMed]

28. Kjellman, M.; Enberg, U.; Höög, A.; Larsson, C.; Holst, M.; Farnebo, L.O.; Sato, H.; Bäckdahl, M. Gelatinase A and membrane-type 1 matrix metalloproteinase mRNA: Expressed in adrenocortical cancers but not in adenomas. World J. Surg. 1999, 23, 237-242. [CrossRef]

29. Kolomecki, K.; Stepien, H.; Bartos, M.; Kuzdak, K. Usefulness of VEGF, MMP-2, MMP-3 and TIMP-2 serum level evaluation in patients with adrenal tumours. Endocr. Regul. 2001, 35, 9-16.

30. De Fraipont, F.; El Atifi, M.; Gicquel, C.; Bertagna, X.; Chambaz, E.M.; Feige, J.J. Expression of the angiogenesis markers vascular endothelial growth factor- $\mathrm{A}$, thrombospondin-1, and platelet-derived endothelial cell growth factor in human sporadic adrenocortical tumors: Correlation with genotypic alterations. J. Clin. Endocrinol. Metab. 2000, 85, 4734-4741. [CrossRef]

31. Bernini, G.P.; Moretti, A.; Bonadio, A.G.; Menicagli, M.; Viacava, P.; Naccarato, A.G.; Iacconi, P.; Miccoli, P.; Salvetti, A. Angiogenesis in human normal and pathologic adrenal cortex. J. Clin. Endocrinol. Metab. 2002, 87, 4961-4965. [CrossRef]

32. Geervliet, E.; Bansal, R. Matrix metalloproteinases as potential biomarkers and therapeutic targets in liver diseases. Cells 2020, 9 , 1212. [CrossRef] [PubMed]

33. Kirschner, L.S. Review: Emerging treatment strategies for adrenocortical carcinoma: A new hope. J. Clin. Endocrinol. Metab. 2006, 91, 14-21. [CrossRef] [PubMed]

34. Volante, M.; Sperone, P.; Bollito, E.; Frangipane, E.; Rosas, R.; Daffara, F.; Terzolo, M.; Berruti, A.; Papotti, M. Matrix metalloproteinase type 2 expression in malignant adrenocortical tumors: Diagnostic and prognostic significance in a series of 50 adrenocortical carcinomas. Mod. Pathol. 2006, 19, 1563-1569. [CrossRef]

35. Weismann, D.; Briese, J.; Niemann, J.; Grüneberger, M.; Adam, P.; Hahner, S.; Johanssen, S.; Liu, W.; Ezzat, S.; Saeger, W.; et al. Osteopontin stimulates invasion of NCI-h295 cells but is not associated with survival in adrenocortical carcinoma. J. Pathol. 2009, 218, 232-240. [CrossRef]

36. Sapino, A.; Marchiò, C.; Senetta, R.; Castellano, I.; Macrì, L.; Cassoni, P.; Ghisolfi, G.; Cerrato, M.; D’Ambrosio, E.; Bussolati, G. Routine assessment of prognostic factors in breast cancer using a multicore tissue microarray procedure. Virchows Arch. 2006, 449, 288-296. [CrossRef] [PubMed]

37. Virtanen, I.; Korhonen, M.; Petäjäniemi, N.; Karhunen, T.; Thornell, L.E.; Sorokin, L.M.; Konttinen, Y.T. Laminin isoforms in fetal and adult human adrenal cortex. J. Clin. Endocrinol. Metab. 2003, 88, 4960-4966. [CrossRef]

38. Volante, M.; Bollito, E.; Sperone, P.; Tavaglione, V.; Daffara, F.; Porpiglia, F.; Terzolo, M.; Berruti, A.; Papotti, M. Clinicopathological study of a series of 92 adrenocortical carcinomas: From a proposal of simplified diagnostic algorithm to prognostic stratification. Histopathology 2009, 55, 535-543. [CrossRef]

39. Senger, D.R.; Perruzzi, C.A.; Gracey, C.F.; Papadopoulos, A.; Tenen, D.G. Secreted phosphoproteins associated with neoplastic transformation: Close homology with plasma proteins cleaved during blood coagulation. Cancer Res. 1988, 48, 5770-5774.

40. Shijubo, N.; Uede, T.; Kon, S.; Nagata, M.; Abe, S. Vascular endothelial growth factor and osteopontin in tumor biology. Crit. Rev. Oncog. 2000, 11, 135-146.

41. Rodrigues, L.R.; Teixeira, J.A.; Schmitt, F.L.; Paulsson, M.; Lindmark-Mänsson, H. The role of osteopontin in tumor progression and metastasis in breast cancer. Cancer Epidemiol. Biomark. Prev. 2007, 16, 1087-1097. [CrossRef]

42. Zhang, J.; Takahashi, K.; Takahashi, F.; Shimizu, K.; Ohshita, F.; Kameda, Y.; Maeda, K.; Nishio, K.; Fukuchi, Y. Differential osteopontin expression in lung cancer. Cancer Lett. 2001, 171, 215-222. [CrossRef]

43. Kim, J.-H.; Skates, S.J.; Uede, T.; Wong, K.; Schorge, J.O.; Feltmate, C.M.; Berkowitz, R.S.; Cramer, D.W.; Mok, S.C. Osteopontin as a potential diagnostic biomarker for ovarian cancer. JAMA 2002, 287, 1671-1679. [CrossRef] [PubMed]

44. Ue, T.; Yokozaki, H.; Kitadai, Y.; Yamamoto, S.; Yasui, W.; Ishikawa, T.; Tahara, E. Co-expression of osteopontin and CD44v9 in gastric cancer. Int. J. Cancer 1998, 79, 127-132. [CrossRef]

45. Gotoh, M.; Sakamoto, M.; Kanetaka, K.; Chuuma, M.; Hirohashi, S. Overexpression of osteopontin in hepatocellular carcinoma. Pathol. Int. 2002, 52, 19-24. [CrossRef] [PubMed]

46. Forootan, S.S.; Foster, C.S.; Aachi, V.R.; Adamson, J.; Smith, P.H.; Lin, K.; Ke, Y. Prognostic significance of osteopontin expression in human prostate cancer. Int. J. Cancer 2006, 118, 2255-2261. [CrossRef] [PubMed] 
47. Cappia, S.; Righi, L.; Mirabelli, D.; Ceppi, P.; Bacillo, E.; Ardissone, F.; Molinaro, L.; Scagliotti, G.V.; Papotti, M. Prognostic role of osteopontin expression in malignant pleural mesothelioma. Am. J. Clin. Pathol. 2008, 130, 58-64. [CrossRef] [PubMed]

48. Overgaard, J.; Eriksen, J.G.; Nordsmark, M.; Alsner, J.; Horsman, M.R. Plasma osteopontin, hypoxia, and response to the hypoxia sensitiser nimorazole in radiotherapy of head and neck cancer: Results from the DAHANCA 5 randomised double-blind placebo-controlled trial. Lancet Oncol. 2005, 6, 757-764. [CrossRef]

49. Vergis, R.; Corbishley, C.M.; Norman, A.R.; Bartlett, J.; Jhavar, S.; Borre, M.; Heeboll, S.; Horwich, A.; Huddart, R.; Khoo, V.; et al. Intrinsic markers of tumour hypoxia and angiogenesis in localised prostate cancer and outcome of radical treatment: A retrospective analysis of two randomised radiotherapy trials and one surgical cohort study. Lancet Oncol. 2008, 9, 342-351. [CrossRef]

50. Kobayashi, T.; Chanmee, T.; Itano, N. Hyaluronan: Metabolism and function. Biomolecules 2020, 10, 1525. [CrossRef]

51. Yuan, Y.; Liu, Q.; Zhang, F.; Luo, W. Effect of ligand-receptor interaction of osteopontin-CD44 on the expression of hyaluronic acid in human knee osteoarthritic chondrocytes in vitro. Zhong Nan Da Xue Xue Bao. Yi Xue Ban J. Cent. South Univ. Med. Sci. 2020, 45, 1015-1023. [CrossRef]

52. Tiainen, S.; Oikari, S.; Tammi, M.; Rilla, K.; Hämäläinen, K.; Tammi, R.; Kosma, V.-M.; Auvinen, P. High extent of O-GlcNAcylation in breast cancer cells correlates with the levels of HAS enzymes, accumulation of hyaluronan, and poor outcome. Breast Cancer Res. Treat. 2016, 160, 237-247. [CrossRef] [PubMed]

53. Sapudom, J.; Müller, C.D.; Nguyen, K.-T.; Martin, S.; Anderegg, U.; Pompe, T. Matrix remodeling and hyaluronan production by myofibroblasts and cancer-associated fibroblasts in 3D collagen matrices. Gels 2020, 6, 33. [CrossRef] [PubMed]

54. Adamia, S.; Kriangkum, J.; Belch, A.R.; Pilarski, L.M. Aberrant posttranscriptional processing of hyaluronan synthase 1 in malignant transformation and tumor progression. Adv. Cancer Res. 2014, 123, 67-94. [CrossRef] [PubMed]

55. De Sá, V.K.; Rocha, T.P.; Moreira, A.; Soares, F.A.; Takagaki, T.; Carvalho, L.; Nicholson, A.G.; Capelozzi, V.L. Hyaluronidases and hyaluronan synthases expression is inversely correlated with malignancy in lung/bronchial pre-neoplastic and neoplastic lesions, affecting prognosis. Braz. J. Med. Biol. Res. 2015, 48, 1039-1047. [CrossRef]

56. Poukka, M.; Bykachev, A.; Siiskonen, H.; Tyynelä-Korhonen, K.; Auvinen, P.; Pasonen-Seppänen, S.; Sironen, R. Decreased expression of hyaluronan synthase 1 and 2 associates with poor prognosis in cutaneous melanoma. BMC Cancer 2016, 16, 313. [CrossRef] 